\title{
Toward the Digitalisation of the Organisational Learning Capability to Enhance Organisational Performance
}

\author{
MOHAMED ALKARAEEN \\ -Researcher in Cranfield University Cranfield University, \\ Cranfield, Bedfordshire MK43 0AL, \\ UNITED KINGDOM \\ AHMED AL-ASHAAB \\ -Reader in Lean Product Development Cranfield University, \\ Cranfield, Bedfordshire MK43 0AL, \\ UNITED KINGDOM,
}

\begin{abstract}
Public organisations provide training to enhance their employee's capabilities to provide better services. Public organisations use different learning methods to enhance their employee's skills and service offering. Therefore, public organisations are considering different learning programmes such as classroom training, coaching, mentoring etc. For the organisations to be effective in providing the learning programs to their employees, there is a need to have an approach to support these efforts. This study suggests that Organisational Learning Capability (OLC) is the right approach to do that. This is because OLC facilitates the learning process. The study proposes an OLC model consists of the key elements that represent the definition of OLC; these are the learning processes, enablers, influential factors. This paper explores how organisations can bridge the gap between investments in learning initiatives and improvement in service provision in public organisations. The context of this study is the creation of a set of learning and development programs in the public services organisations. The top OLC model helps to define all other learning programmes where the coaching learning program is presented in this paper.
\end{abstract}

Key-Words: - Organisational Learning capability, Learning programmes, Public services organisations, Coaching learning programme, Learning process in organisations.

Received: September 15, 2020. Revised: January 19, 2021. Accepted: February 1, 2021. Published: February 11, 2021.

\section{Introduction}

The advent of new digital technologies and the gig economy present an opportunity for revisiting the way learning programmes are conducted. Organisations invest massively in learning programmes to upskill human talent and improve service offering. In 2016, \$359 billion was spent globally [1]. However, these investments usually lack the expected impact on service performance: three quarters of managers and employees are dissatisfied and lack the required skill to do their jobs [2]. Organisations are considering digital technologies to address these challenges, but, without the right deployment strategy, they risk committing the same mistakes and using technology for waste automation [3]. Thus, adopting digital technologies to deliver impactful and costeffective learning programmes requires an 
aligned deployment framework that account for the challenges digital technologies pose to learning, including employees' difficulty to undertake and complete training [4]

This paper explores how organisations can bridge the gap between investments in learning programmes and service performance in public sector organisations. The author adopts an organisational learning capability (OLC) perspective to study what strategic enablers and influential factors affecting the link between digital technologies and organisational learning. OLC emphasises on the ability of organisations to acquire and translate knowledge from external sources, operations, experiences and initiatives into improvement changes [5, 6]. OLC addresses the individual, group and organisational levels to realise the management goals [7, 8, 9]. Exploring OLC has the potential to highlight a distinctive framework that advantage technological investments in learning.

The context of this study is the creation of a set of learning programmes in public sector organisations. The authors built a mixedmethods field study focusing on coaching learning programs. Data were collected and analysed during three phases. First, the theoretical foundations of OLC were reviewed, recording different key factors. Second, semistructured interviews were conducted with multiple experienced participants across industrial sectors in Europe and UAE to capture their perspectives of the organisational learning programs enablers and challenges. Third, findings from the previous two phases were reconciled to produce a model for OLC which includes a detailed analysis of the role that digital technologies play in enabling the organisational learning.

\section{Literature Review}

\subsection{The Organisational Learning Capabilities}

Research on organisational learning has focused on the "change in the organisation that occurs as the organisation acquires experience" [10], from at least three perspectives: behavioural, knowledge and systems. Behavioural researchers have compared concepts from individual learning to organisational learning, highlighting the role of bounded rationality and the challenges of learning under uncertainty $[11,12,13]$. Organisational learning researchers focused on understanding the role of knowledge in learning Finally, researchers took a learning systems angle, finding management practices that foster organisational learning $[14,15,16$, $17,18,19]$.

The study operationalises OLC as an organisation's ability to acquire and translate knowledge from external sources, operations, experiences and initiatives into improvement changes at the individual, group and organisational level to realise the management goals [5]. While research on organisational learning argues that learning causes myopia, prevents innovation and causes structural rigidity $[12,11,13]$, OLC provides an alternative vantage point to analyse those challenges. It argues that some organisational structures, processes and values can become enablers and influential factors for innovation and adaptation and improvements [20, 21].

\subsection{Enablers of the Organisational Learning Capability}

Different opinions about organisational learning enablers can be broadly classified in acquire and capture knowledge enablers, which allow the organisation to grab learning experiences 
from its employees, associates, competitors and the environment and establish a mode of documentation translate knowledge enablers, which transform knowledge sources into learning and integrate it across the organisation, including dissemination mode, and skill development $[22,8]$, realise management goals enablers, which promote common mental models (e.g. mission and vision) [23, 8] and reward systems [8]. Finally, systemic change enablers such as those that focus on leadership commitment, empowerment and experimentation $[8,22,24,25,26]$. Table 1 present an example of enablers considered in this study. Table 1 present OLC enablers that are identified from the reviewed literature.

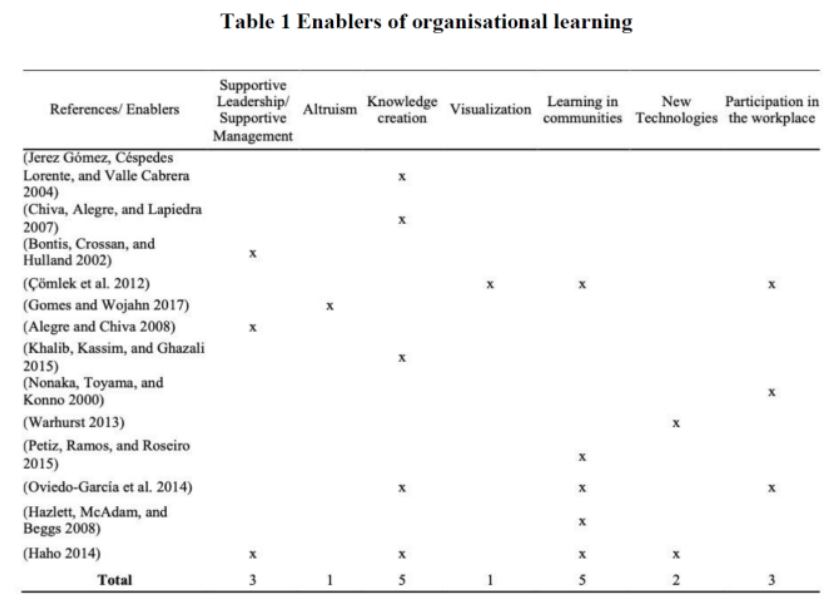

\subsection{Facilitating Factors for Implementation of OLC}

Facilitating factors describe the "organisational and managerial characteristics or factors that facilitate the organisational learning process or allow an organisation to learn" [27]. Some studies referred to facilitating factors as the dimensions of learning and have been used as components of instruments to measure learning. These dimensions are derived from both the Learning Organisation literature [28], and the Organisational Learning [29, 30]. A summary of the facilitating factors are presented below:
Table 2 Factors that facilitate learning in organisation

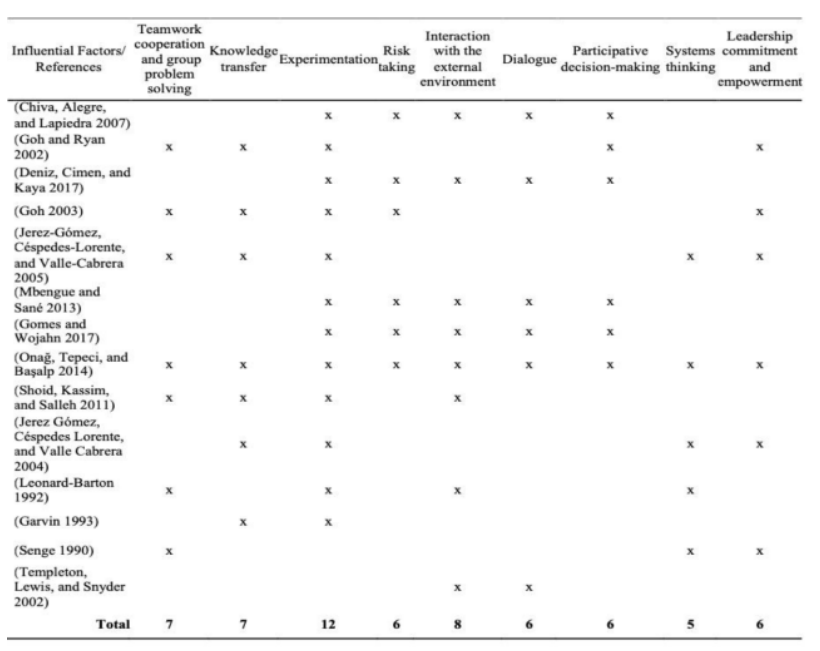

\subsection{Digitalisation of learning process}

Recently, digital innovations have blossomed due to progress in infrastructure and algorithms, and emergence of a new generation of digital savvies. This innovations have profound implications for corporate management and learning [31, 32, 33, 34, 35, 36, 37]. Three mechanisms are to note: improving structural performance, (cost-related efficiency gains), enhancing relational performance (collaboration quality across different teams) and promoting new product development performance [34]. Performance benefits are only achieved if the appropriate conditions exist; an integrated development environment and other tactics need to be in place to reduce the risk of derailing innovation practices [33].

Researchers found the use of digital platforms for education can benefit multiple dimensions of learning programmes through; ease of access to knowledge, emergence of a massive open online courses, integration with industries, global mobility of learners, competitive landscape, objectivity of assessment, and time dedicated per instructor $[38,39]$.

For digital technologies to deliver, organisations need to align digital innovation 
with corporate goals, foster the right organisational culture, build talent/roles with the right skills on the effective appropriation of digital instruments [40, 41], and get leadership buy-in [42, 41]. However, these digitalisation enablers have not been integrated with the application of learning programmes. Two gaps are addressed; 1) a need for a well-defined OLC model to help organisations introduce and implement learning programmes costeffectively. 2) Most of the papers have not addressed comprehensively compiling the facilitating factors of learning process in organisations.

\section{Research design and methodology}

This study seeks to gain a better understanding of the learning practices in public sector to support the development of an OLC model that encourages learning culture activities, utilising digital technology to enhance performance and service offering. A structured interview protocol using face to face and video meetings was used to collect data. The protocol covered key aspects mentioned in the literature including learning processes, enablers, influential factors and digital enabling technology. The study interviewed 37 employees from 30 public sector organisations from seven countries. The sample, shown in Table 3, includes managers in healthcare, education, social care, local authorities and law enforcement sectors.
Table 3 Field study participants

\begin{tabular}{|c|c|c|c|c|}
\hline & Business Sector & Country & Position & $\begin{array}{c}\text { Industry } \\
\text { Experience } \\
\text { (years) }\end{array}$ \\
\hline & Police Force & Spain & Caporal & 14 \\
\hline${ }_{3}^{2}$ & $\begin{array}{l}\text { Police Force } \\
\text { Police Force }\end{array}$ & $\begin{array}{l}\text { Spain } \\
\text { France }\end{array}$ & $\begin{array}{l}\text { Guardia Civil } \\
\text { Officer }\end{array}$ & $\begin{array}{l}30 \\
36\end{array}$ \\
\hline & $\begin{array}{l}\text { Police Force } \\
\text { Police For }\end{array}$ & $\begin{array}{l}\text { France } \\
\text { Finand }\end{array}$ & Head of education & 25 \\
\hline$s$ & Police Force & Norway & Head of studies & 30 \\
\hline 6 & Police Force & France & Super intendant & 18 \\
\hline 7 & Police Force & & Head of strategic planning & 16 \\
\hline 8 & Police Force & UAE & Head of smart city centre & \\
\hline 9 & Law Enforcement & UAE & $\begin{array}{l}\text { Head of planning of training } \\
\text { section }\end{array}$ & 8 \\
\hline 10 & Law Enforcement & UAE & Head scholarship section & 15 \\
\hline 11 & Law Enforcement & UAE & & 16 \\
\hline 12 & Healthcare & Poland & Education Solutions Lead & 10 \\
\hline $\begin{array}{l}13 \\
14\end{array}$ & $\begin{array}{l}\text { Healthcare } \\
\text { Healthcare }\end{array}$ & $\begin{array}{l}\text { France } \\
\text { UK }\end{array}$ & $\begin{array}{l}\text { GP } \\
\text { Head of Practice Education }\end{array}$ & $\begin{array}{l}40 \\
22\end{array}$ \\
\hline 15 & Healthcare & France & $\begin{array}{l}\text { Head of Practice Education } \\
\text { Head of the statistics department }\end{array}$ & \\
\hline 16 & Healthcare & UAE & Head or the stanst GP departinent & \\
\hline 17 & Healtheare & UAE & Department head & \\
\hline & & UAE & Department head & 10 \\
\hline 19 & Healthcare & & Specialist doctor & \\
\hline 20 & Healthcare & UAE & Specialist doctor & 18 \\
\hline 21 & $\begin{array}{l}\text { Governmental } \\
\text { Agency }\end{array}$ & France & Consultant on Training & 8 \\
\hline 22 & Education & Poland & Head of the Primary School & 35 \\
\hline 24 & $\begin{array}{l}\text { Education } \\
\text { Education }\end{array}$ & $\begin{array}{l}\text { France } \\
\text { Poland }\end{array}$ & $\begin{array}{l}\text { Certified French teacher } \\
\text { Vice-rector }\end{array}$ & $\begin{array}{l}24 \\
20\end{array}$ \\
\hline 25 & Education & Poland & Head of Regional Methodological & 20 \\
\hline 26 & Education & Spain & $\begin{array}{l}\text { and Educational Centre } \\
\text { Teacher }\end{array}$ & 12 \\
\hline & Education & Spain & Subdirector $/$ Teacher & 32 \\
\hline 28 & Education & France & Teacher & 20 \\
\hline 29 & Education & France & University professor & 35 \\
\hline 30 & Education & UAE & Faculty Heading & 25 \\
\hline 32 & $\begin{array}{l}\text { Education } \\
\text { Education }\end{array}$ & $\begin{array}{l}\text { UAE } \\
\text { UAE }\end{array}$ & $\begin{array}{l}\text { Teacher } \\
\text { Teacher }\end{array}$ & $\begin{array}{l}15 \\
17\end{array}$ \\
\hline 33 & Council & UK & $\begin{array}{l}\text { Learning \& Development } \\
\text { Consultant }\end{array}$ & 30 \\
\hline 34 & $\begin{array}{l}\text { Governmental } \\
\text { Agency }\end{array}$ & Poland & Head of Training & 10 \\
\hline 35 & Governmental & Spain & Responsable de Formación & 6 \\
\hline 36 & Governmental & France & Training manager & 8 \\
\hline 37 & $\begin{array}{l}\text { Agency } \\
\text { Security }\end{array}$ & France & Human Resources & 10 \\
\hline
\end{tabular}

\section{Data analysis}

We rated organisation using a 1-5 Likert scale where higher scores indicate greater effectiveness and/or adoption on 4 areas: learning processes, enablers, facilitating factors, and challenges in adopting digitally enabled learning processes. The same measurement applied to the frequency wherever it occurred. Data were filtered to include only inputs with an average effectiveness above 3 .

Figure 1 shows that public service organisations are performing all the needed tasks to conduct any learning programme. Designing, evaluation of the learning programmes and the evaluation of the gained knowledge tasks are less effective which should be considered in the final model.

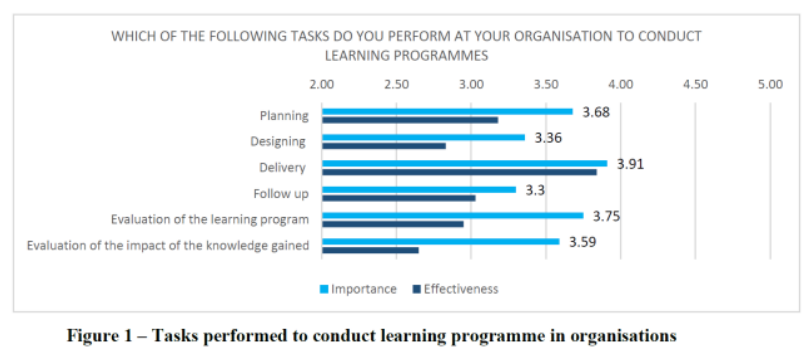


Figure 2 summarise the key learning facilitating factors in public sector ranked by importance according to the interviewees. These factors are important to support the execution of the different activities of the defined learning process.

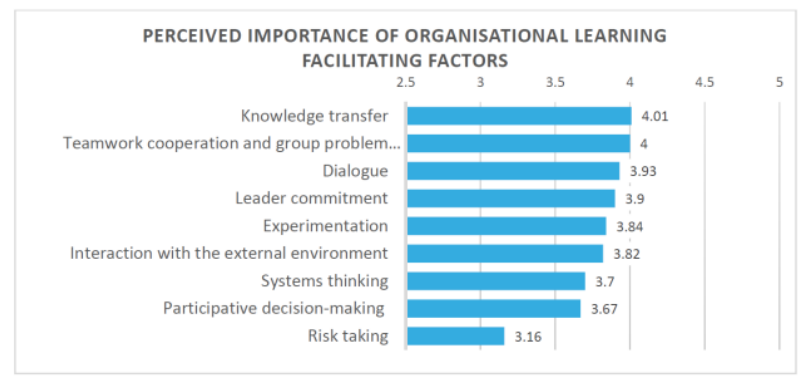

Figure 2 - Learning Processes Facilitating Factors

Interviewees discussed the role of digital technologies in enabling the implementation of learning programmes. Virtual learning environments and business games supported learning in public organisations, particularly, when they are accessed through different devices, including smart phones and tablets. However, several challenges emerge from implementing these digital technologies (see Figure 3), including the adoption resistance from older employees and privacy and cyber security concerns. The analysis shows the importance of creating an organisational capability to reap benefits from digital technologies: from improving the employee's digital skills to facilitate access to specifying the right structures to monitor execution of learning. Therefore, the intended OLC model should be developed to address and overcome these challenges.

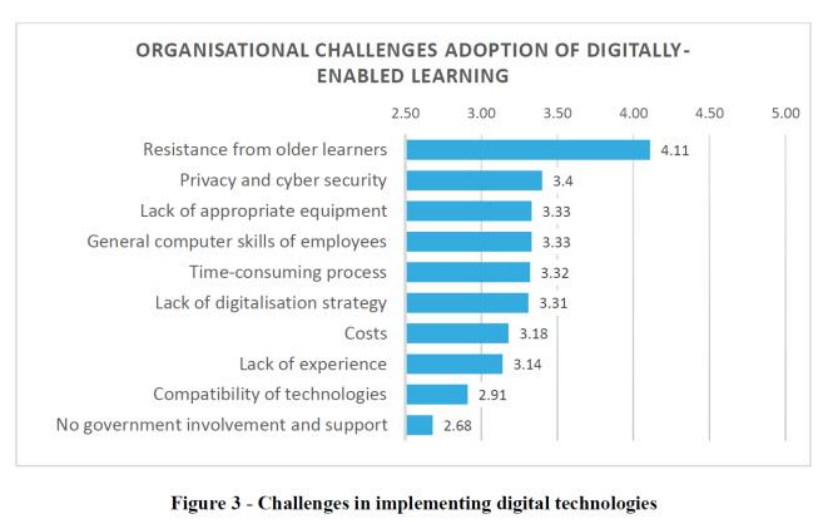

\section{The Organisational Learning}

\section{Capabilities Model}

The OLC model shown in Figure 4 represents one of the main contributions of this research which consists of three main elements; learning routines, influential factors, and enabler. The model encapsulates elements which were discussed in the literature review and endorsed via the field study (questionnaires and structured interviews) both in the UAE and Europe. The proposed OLC model is a graphical representation of the OLC definition which is to say that "OLC is the facilitation of a process to ensure that the organisation is learning from its operations and experiences of different projects and initiatives. This learning process is influenced by certain factors that are directly related to the performance of both employees and service provision." [26, 21].

The OLC model presents a process for public sector organisations to learn via different stages with several tasks in each stage. The model shows several key influential factors that should be taken into account to ensure the effectiveness of the learning process. Several enablers have also been captured to facilitate an effective application of the learning in the organisation. Previous knowledge and experiences are going to be used to support the identification of any knowledge gaps in the employee's skills, and supporting the defined new learning process. 


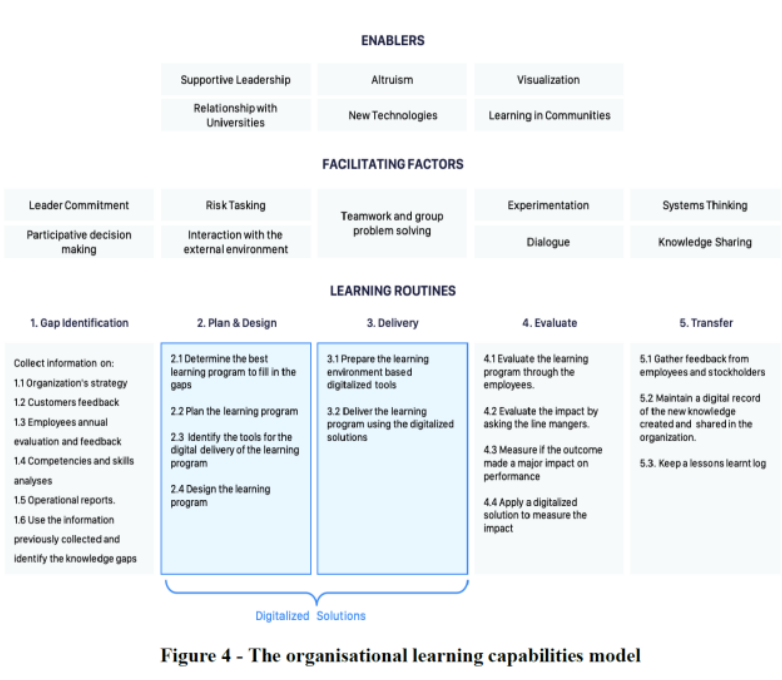

\subsection{Learning processes and routines}

Previous studies on Organizational Learning focused on the four Organizational Learning Processes [10]: knowledge creation, knowledge retention [43, 44, 45], knowledge transfer [46, 47] and knowledge search [48]. This paper builds upon such theoretical framework and discusses five routines that enable the organizational learning processes presented above. These routines are knowledge identification, learning program selection, planning and designing, the delivery of the learning programs, the Impact Evaluation and knowledge Sharing. The following paragraphs present the routines that enable the aforementioned learning process.

Gap identification: Prior to starting the learning process itself, knowledge gap identification is performed to determining the gap between performance standards and employees' skills. During process, the organisational strategy, customers' feedback and performance reviews are analysed to find potential missing skills. This results into a competence matrix that is used to tailor learning programmes needed.

Plan and Design: In this stage specific are selected to close the identified knowledge gap. Here, organisations select the learning programmes - classroom training, apprenticeships, coaching, a Gemba Walk or a customized degree - that better fits employee's needs. This routine includes selecting or developing the right digitalised tools to enable proper implementation of the learning programme.

Delivery: The organization starts to prepare a mixture of methods to deliver the learning programmes. The most popular ones are faceto-face delivery, virtual, and blended delivery. The latter is one of the most effective methods as it combines the virtues of both providing a good balance between the engagement and empathy from face-to-face methods with the flexibility and adaptability of virtual methods, providing a nimbler yet effective learning. The progress of all the delivery should be digitally recorded to be used in future analysis.

Evaluation: monitoring of learning programs delivery, using digital tools should carry on until throughout learning cycle. The entire program should be evaluated to ensure that objectives are met, and gaps are mended. Feedback should be collected from all stakeholders and should be analysed. Programs impact on employees' line managers and overall organizational performance should be studied.

Transfer: learning programmes should produce valuable knowledge to the organisation which should be captured and shared across the organisation through:

- Gathering feedback from employees, managers, and various stakeholders.

- Digitally documenting the progress, impact and lesson learnt log. 


\subsection{Enablers}

Six enablers (Supportive leadership, relationship with Universities, Altruism, data visualization, new technologies, learning in Communities) play a key role in public organisation learning; they yielded the right environment to maximize the benefits of learning programmes.

\subsection{Facilitating Factors}

Nine factors (knowledge sharing, dialogue, participative decision making, interaction with the external environment, experimentation, risk taking, systems thinking, leader commitment, and teamwork cooperation and group problem solving) were associated with positive learning experiences and improved performance in public organisations.

\subsection{Coaching learning programs within OLC environment}

The International Coaching Federation identifies coaching as a "thought-provoking and creative process that inspires people to maximize their personal and professional potential". Coaching is used to enhance learning and increase organizational effectiveness and as a learning \& development approach to generate individual learning that results in collective learning, to be transferred to organizational learning.

The coaching learning program process shown in Figure 5, presents the steps of creating an effective coaching. The process represents the stages from the OLC model presented in Figure 4; plan and design, learning program delivery and the impact evaluation.

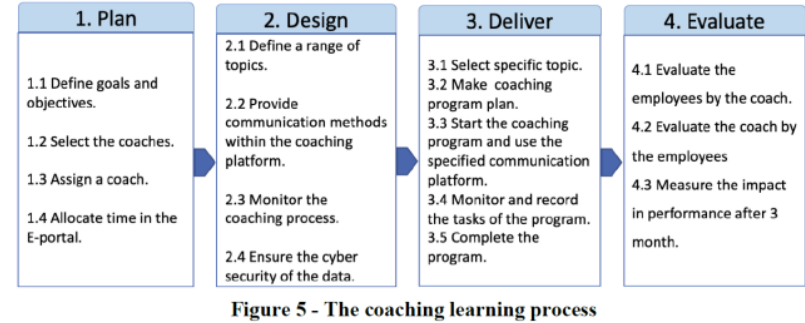

\subsubsection{Coaching Plan}

Defining goals and objectives including a program mission statement. The coaching portal should have a dedicated section to allow process managers to enter goals that will be visible to all stakeholders. Such goals will be utilised later during the evaluation process to ensure the effectiveness of the program.

Select coaches: Identify and E-certify the selected coaches by providing an e-learning course through the coaching platform.

Assign a coach: Coaches are assigned their coachees based on their experience and ability to create the required effect and to achieve the set goals.

Allocate time in the E-portal: the system should allow for time booking and schedules creation on both the coach and coachee calendar.

\subsubsection{Design Coaching}

Organisations should have an inventory of coaching topics as a result of the learning needs analysis. Such topics are organised within the coaching portal. Once coaching goals are set for an individual, certain topics get selected to be the focus of coaching. The digitalised portal offers various ways of communicating such as emails, video webinars. This also applies to "face-to-face coaching" as the platform can be used to keep schedules and book venues for meetings. The progress can be monitored 
regularly and automatically through the digital portal.

\subsubsection{Delivering Coaching}

The coach should set the coaching plan and start the coaching. All steps of delivery should be documented through the digital portal. Program managers should continuously ensure the usage of the coaching portal and ensure that coaching progress is as desired. When the programme ends reports could be issued and preparation for the final evaluation stage should start.

\subsubsection{Coaching Evaluation}

The evaluation process involves:

Evaluation of the employees by the coach: The coach evaluates coaches using the coaching management portal thought a function normally called progress tracking. Progress tracking will allow the coach to review the progress notes and steps and to fill in the required data electronically.

Evaluation of the coach by the employees: Evaluators via the digitalised portal should be able to share the evaluation forms with the coaches. This data should be analysed to measure the effectiveness and the performance of the coach.

Measure the impact in performance: the impact of the programs will be measured after a set period (for example 3 months) to ensure that the program is consistent with the set objectives. This will be done by contacting the coachees' line mangers and measuring the improvements in the productivity and strategic KPIs of their unites.

\section{Conclusion}

Public sector organisations are keen to improve the skills of their employees. The traditional approach of providing mainly training is not good anymore. Therefore, public sector organisations are considering different learning programs such as coaching, mentoring etc. This study suggests that OLC is the right approach to boost the learning as OLC facilitates the learning process. The proposed OLC model consists of the key elements that represent the definition of OLC; these are the learning processes, enablers, influential factors and the enabling technologies. The OLC model helps to define all other learning programs where the coaching learning program is presented in this paper. A digitlised software demonstrator is being developed based on the tasks of the coaching learning programme process. The digitlised software demonstrator will be used in a case study in a public service organisation as a future work.

\section{References:}

[1] B. Borzykowski, Training is oftens seen as a bore and a chore. Is there a way to make it better?, BBC, 2017.

[2] S. Glaveski, Where Companies Go Wrong with Learning and Development, Harvard Business Review, 2019, pp. 1-7.

[3] M. Holweg, J. Davies, A. De Meyer, B. Lawson, R. W. Schmenner, R, Improving Processes, In Process Theory: The Principles of Operations Management, pp.167-192.

[4] A. C. Edmondson, Teaming: How Organizations Learn, Innovate, and Compete in the Knowledge Economy, John Wiley \& Sons, 2012.

[5] D. Leonard- Barton, Core Capabilities and Core Rigidities: A Paradox in Managing New Product Development, Strategic Management Journal, Vol.13, No. S1, 1992, pp. 111-125.

[6] M. Popper, R. Lipshitz, Organizational Learning Mechanisms: A Structural and Cultural Approach to Organizational Learning, The Journal of Applied Behavioral Science, Vol.34, No.2, 1998, pp.161-179. 
[7] M. M. Crossan, H. W. Lane, R. E. White, An Organizational Learning Framework: From Intuition to Institution, Academy of Management Review, Vol.24, No.3, 1999, pp. 522-537.

[8] S. C. Goh, Improving Organizational Learning Capability: Lessons from Two Case Studies, The Learning Organization, Vol.10, No. 4, 2003, pp. 216-227.

[9] T. B. Lawrence, M. K. Mauws, B. Dyck, R. F. Kleysen, The Politics of Organizational Learning: Integrating Power into the 4I Framework, Academy of Management Review, Vol.30, No.1., 2005, pp.180-191.

[10] L. Argote, E. Miron-Spektor Organizational Learning: From Experience to Knowledge, Organization Science, Vol.22, No. 5, 2011, pp. 1123-1137.

[11] J. G. March, J. P. Olsen, The Uncertainty of the Past: Organizational Learning Under Ambiguity, European Journal of Political Research, Vol.3, No.2, 1975, pp. 147-171.

[12] D. A. Levinthal, J. G. March, The Myopia of Learning, Strategic Management Journal, Vol.14, No.2 S, 1993, pp. 95-112.

[13] H. A. Simon, Bounded Rationality and Organizational Learning, Organization Science, Vol.2, No.1, 1991, pp. 125-134.

[14] P. M. Senge, The Fifth Discipline: The Art and Practice of the Learning Organization. Broadway Business, 2006.

[15] A. Örtenblad, Senge's Many Faces: Problem or Opportunity?' The Learning Organization, 2007.

[16] O. Bak, Universities: Can They Be Considered as Learning Organizations?' The Learning Organization, 2012.

[17] R. Caldwell, Leadership and Learning: A Critical Reexamination of Senge's Learning Organization, Systemic Practice and Action Research, Vol. 25, No.1, 2012a, pp. 39-55.

[18] R. Caldwell, Systems Thinking, Organizational Change and Agency: A Practice Theory Critique of Senge's Learning Organization, Journal of Change Management, Vol.12, No.2, 2012b, pp. 145-164.

[19] P. Shrivastava, A Typology of Organizational Learning Systems, Journal of Management Studies, Vol.20, No.1, 1983, pp. 7-28.

[20] D. Jiménez-Jiménez, R. Sanz-Valle, Innovation, Organizational Learning, and Performance, Journal of Business Research, Vol.64, No.4, 2011, pp. 408-417.

[21] J. Alegre, R. Chiva, Assessing the Impact of Organizational Learning Capability on Product Innovation Performance: An Empirical Test, Technovation, Vol. 28, No. 6, 2008, pp. 315-326.
[22] P. Jerez-Gómez, J. Céspedes-Lorente, R. ValleCabrera, Organizational Learning Capability: A Proposal of Measurement, Journal of Business Research, Vol.58, No.6, 2005, pp. 715-725.

[23] P. M. Senge, The Fifth Discipline: The Art and Practice of the Learning Organization, Currency, 1990.

[24] P. Jerez-Gómez, J. Céspedes-Lorente, R. ValleCabrera, Training Practices and Organisational Learning Capability, Journal of European Industrial Training, Vol.28, 2004, pp.234-256

[25] V. J. García-Morales, M. M. JiménezBarrionuevo, L. Gutiérrez-Gutiérrez,

Transformational Leadership Influence on Organizational Performance through Organizational Learning and Innovation, Journal of Business Research, Vol.65, No.7, pp. 1040-1050.

[26] A. Moghadam, M. Bakhtiari, M. Raadabadi, M. Bahadori, Organizational Learning and Empowerment of Nursing Status Tehran University of Medical Sciences, Education Strategies in Medical Sciences, Vol.6, No.2, 2013, pp. 113-118. [27] S. C. Goh, G. Richards, Benchmarking the Learning Capability of Organizations, European Management Journal, Vol. 15, No. 5, 1997, pp. 575-583.

[28] G. T. M. Hult, O. C. Ferrell, Global Organizational Learning Capacity in Purchasing: Construct and Measurement, Journal of Business Research, Vol.4, No.2, 1997, pp. 97-111.

[29] R. Chiva-Gómez, The Facilitating Factors for Organizational Learning in the Ceramic Sector, Human Resource Development International, Vol.7, No.2, 2004, pp. 233-249.

[30] R. Chiva, J. Alegre, R. Lapiedra, Measuring Organisational Learning Capability among the Workforce, International Journal of Manpower, Vol.28, 2007, pp. 224-242

[31] A. Noruzy, V. M. Dalfard, B. Azhdari, S. Nazari-Shirkouhi, A. Rezazadeh, Relations between Transformational Leadership, Organizational Learning, Knowledge Management, Organizational Innovation, and Organizational Performance: An Empirical Investigation of Manufacturing Firms, International Journal of Advanced Manufacturing Technology, Vol.64, No.5-8, 2013, pp. 1073-1085.

[32] S. Khin, T. C. F. Ho, Digital Technology, Digital Capability and Organizational Performance: A Mediating Role of Digital Innovation, International Journal of Innovation Science, Vol.11, No.2, 2019, pp. 177-195.

[33] A. Szalavetz, Industry 4.0 and Capability Development in Manufacturing Subsidiaries, Technological Forecasting and Social Change, Vol.145, 2019, pp. 384-395. 
[34] F. M. Schweitzer, M. Handrich, S. Heidenreich, Digital Transformation in the New Product Development Process: The Role of It-Enabled PLM Systems For Relational, Structural, And NPD Performance, International Journal of Innovation Management, Vol.23, No.07, 2018, pp. 1-34

[35] O. Ylijoki, J. Porras, Conceptualizing Big Data: Analysis of Case Studies'. Intelligent Systems in Accounting, Finance and Management [online] 23 (4), 2016, pp. 295-310.

[36] C. Camisón, A. Villar-López, Organizational Innovation as an Enabler of Technological Innovation Capabilities and Firm Performance, Journal of Business Research, Vol.67, No.1, 2014, pp. 2891-2902.

[37] C. Laurell, C. Sandström, K. Eriksson, R. Nykvist, Digitalization and the Future of Management Learning: New Technology as an Enabler of Historical, Practice-Oriented, and Critical Perspectives in Management Research and Learning, Management Learning, Vol. 51, No.1, 2020, pp. 89-108.

[38] M. Wildan Zulfikar, H. U. B. A. Umri, A. I. Bin Hashim, A. R. A. Dahlan, A Business Case for Digital Transformation of a Malaysian-Based University, Proceedings - International Conference on Information and Communication Technology for the Muslim World 2018, 2018, pp. 106-109.

[39] J. A. Sánchez, B. M. Valle, J. Nicolás, J. M. C. De Gea, J.A. García-Berná, A. Toval, J. L. Fernández-Alemán, A. Puptsau, B. Misnevs, (2019) 'Cloud Service as the Driver for University's Software Engineering Programs Digital Transformation'. Procedia Computer Science, Vol.149, 2019, pp. 215-222.

[40] F. Caputo, F., V. Cillo, E. Candelo, Y. Liu, Innovating through Digital Revolution, Management Decision, Vol.57, No.8, 2019, pp. 2032-2051.

[41] G. Vial, Understanding Digital Transformation: A Review and a Research Agenda, Journal of Strategic Information Systems, Vol.28, No.2, 2019, pp. 118-144.

[42] M. I. Muninger, W. Hammedi, D. Mahr, The Value of Social Media for Innovation: A Capability Perspective, Journal of Business Research, Vol.95, 2019, pp. 116-127.

[43] A. Majchrzak, L. P. Cooper, O. E. Neece, O.E. Knowledge Reuse for Innovation, Management Science, Vol.50, No.2, 2004, pp. 174-188

[44] J. E. McGrath, L. Argote, Group Processes in Organizational Contexts, Blackwell Handbook of Social Psychology: Group Processes, 2001.

[45] H. Arrow, J. E. McGrath, J. L. Berdahl, Small Groups as Complex Systems: Formation,
Coordination, Development, and Adaptation, Sage Publications, 2000.

[46] L.Argote, P. Ingram, Knowledge Transfer: A Basis for Competitive Advantage in Firms, Organizational Behavior and Human Decision Processes, Vol. 82, No. 1, 2000, pp. 150-169

[47] B. A. Bechky, Sharing Meaning across Occupational Communities: The Transformation of Understanding on a Production Floor'. Organization Science Vol.14, No.3, 2003, pp. 312-330.

[48] T. Knudsen, D. A. Levinthal, Two Faces of Search: Alternative Generation and Alternative Evaluation, Organization Science, Vol.18, No.1, 2007, pp. 39-54.

[49] N. Bontis, M. M. Crossan, J. Hulland, Managing an Organizational Learning System by Aligning Stocks and Flows, Journal of Management Studies, Vol.39, No.4, 2002, pp. 437-469.

[50] O. Çömlek, H. Kitapçı, V. Çelik, M. Özşahin, The Effects of Organizational Learning Capacity on Firm Innovative Performance, Procedia - Social and Behavioral Sciences, Vol.41, 2012, pp. 367-374

[51] S. Deniz, M. Cimen, S. Kaya, Determining Organizational Learning Capability: A Study in Private Health Care Organizations, International Journal of Research Foundation of Hospital and Health Care Administration, Vol. 5, 2017, pp.1-7

[52] D. Garvin, Building a Learning Organization, Harvard Business Review, 1993, pp. 78-91.

[53] S. C. Goh, P. J. Ryan, Learning Capability, Organization Factors and Firm Performance, Third European conference on organizational knowledge, learning and capabilities, 2002, pp. 1-5

[54] G. Gomes, R. M. Wojahn, Organizational Learning Capability, Innovation and Performance: Study in Small and Medium-Sized Enterprises (SMES), Revista de Administração, Vol.52, 2017, pp. $163-175$

[55] P. Haho, Learning Enablers, Learning Outcomes, Learning Paths, and Their Relationships in Organizational Learning and Change, 2014, Retrieved from University of Oulu: http://jultika. oulu. fi/files/isbn9789526203584. pdf

[56] S. A. Hazlett, R. McAdam, R., V. Beggs, An Exploratory Study of Knowledge Flows: A Case Study of Public Sector Procurement, Total Quality Management and Business Excellence, Vol.19, No. 1-2, 2008, pp.57-66

[57] W. N. Isaacs, Taking Flight: Dialogue, Collective Thinking, and Organizational Learning, Organizational Dynamics, Vol.22, No. 2, 1993, pp. 24-39.

[58] L.H. Khalib, N. A. Kassim, F. I. Ghazali, Organizational Learning Capabilities ( OLC ) toward Job Satisfaction: A Conceptual Framework, Academic Research International, Vol.6, No. 2015, pp. 169-180. 
[59] A. Mbengue, S. Sané, Organizational Learning Capability: Theoretical Analysis and Empirical Study in the Context of Official Development Aid Project Teams, Canadian Journal of Administrative Sciences, Vol.30, 2013, pp. 26-39.

[60] E. Nonaka, R. Toyama, N. Konno, SECI, Ba and Leadership: A Unified Model of Dynamic Knowledge Creation, Long Range Planning, Vol.33, 2000, pp. 5-34.

[61] A. O. Onăg, M. Tepeci, A. A. Başalp, Organizational Learning Capability and Its Impact on Firm Innovativeness, Procedia - Social and Behavioral Sciences, Vol.150, 2014, pp. 708-717.

[62] M. A. Oviedo-García, M. Castellanos-Verdugo, J. García Del Junco, A. Riquelme-Miranda, Organizational Learning Capacity and Its Impact on the Results in a Government Agency in Chile, International Public Management Journal, Vol.17, 2014, pp. 74-110.

[63] S. Petiz, F. Ramos, P. Roseiro, The Use of Information and Communication Technologies in Organizational Learning Practices: A Research Study in an Innovation-Oriented Portuguese Organization, International Journal of Advanced Corporate Learning (IJAC), Vol.8, No.1, 2015, p. 4.

[64] M. S. M. Shoid, N. A. Kassim, M. I. M. Salleh, Organisational Learning Capabilities and Knowledge Performance: A Conceptual Framework, International Conference on Sociality and Economics Development, Vol.10, 2011, pp. 604-608.

[65] G. F. Templeton, B. R. Lewis, C. A. Snyder, Development of a Measure for the Organizational Learning Construct, Journal of Management Information Systems, Vol.19, 2002, pp. 175-218.

[66] R. Warhurst, Hard Times for HRD, Lean Times for Learning?, European Journal of Training and Development, Vol.37, 2013, pp. 508-526.

\section{Creative Commons Attribution License 4.0 (Attribution 4.0 International, CC BY 4.0)}

This article is published under the terms of the Creative Commons Attribution License 4.0 https://creativecommons.org/licenses/by/4.0/deed.en US 